\title{
SEASONAL CHANGES IN BURROWING OF THE COMMON HAMSTER (CRICETUS CRICETUS L., 1758) (RODENTIA: CRICETIDAE) IN THE CITY
}

\author{
Elena A. Katzman, Elena A. Zaytseva, Natalia Yu. Feoktistova, \\ Nikolay N. Tovpinetz, Pavel L. Bogomolov, Ekaterina V. Potashnikova, \\ and Alexey V. Surov \\ A. N. Severtsov Institute of Ecology and Evolution, Russian Academy of Sciences \\ 33 Leninsky Prosp., Moscow 119071, Russia \\ E-mail:feoktistovanyu@gmail.com
}

Received 14 April 2018, revised 17 May 2018, accepted 23 August 2018

\begin{abstract}
Katzman E. A., Zaytseva E. A., Feoktistova N. Yu., Tovpinetz N. N., Bogomolov P. L., Potashnikova E. V., Surov A. V. Seasonal Changes in Burrowing of the Common Hamster (Cricetus cricetus L., 1758) (Rodentia: Cricetidae) in the City. Povolzhskiy Journal of Ecology, 2018, no. 3, pp. 251-258 (in Russian). DOI: https://doi.org/10.18500/1684-7318-2018-3-251-258
\end{abstract}

The Common hamster (Cricetus cricetus) has been intensively colonizing cities during the last decades. Changes in the burrow numbers and their distribution over an area might be important indicators of the population status for the Common hamster in an urban environment. In this study, we consider the character of the burrow distribution on the experimental plot ( 2.2 ha) situated in the park of Simferopol City, Russian Federation. The brushwood and tree vegetation on this plot had been previously mapped in detail. Hamster burrows were put on the map once a quarter during a year. The peak of burrowing activity is shown to be in November. Interestingly, the ground activity of hamsters continued even in the coldest month (January) of the year but the number of used burrows was very low. The squares where both trees and burrows were present (by average annual indicators) was met significantly more frequently than burrows in the tree-free squares $\left(P=0.02 ; \chi^{2}=5.2\right)$ but this was not the case for the winter and spring seasons. We assume that the connection of burrows with arboreous vegetation facilitates digging, ensures better protection from predators and is a food source. All these factors ensure favorable conditions for the high abundance of the Common hamster in the urban environment.

Key words: Common hamster, burrow, urban population, vegetation.

DOI: https://doi.org/10.18500/1684-7318-2018-3-251-258

\section{INTRODUCTION}

During the last decades, urbanization on the global scale is constantly progressing and the urban human population is expected to increase by 2.5 billion in the next 30 years (World urbanization prospects..., 2014). This process represents an unintentional worldwide experiment that can provide insights into how animals will respond to future changes of environmental and anthropogenic parameters (Lahr et al., 2018). New human settlements initiate the process of degradation of natural habitats which are substituted by new ones with unusual niches, settled by variable animal species.

The Common hamster (Cricetus cricetus) is a species intensively colonizing urban landscapes for several decades in Western Europe and in some Russian cities, such as

(C) Katzman E. A., Zaytseva E. A., Feoktistova N. Yu., Tovpinetz N. N., Bogomolov P. L., Potashnikova E. V., Surov A. V., 2018 
Vladimir, Nalchik, Kislovodsk, Omsk, etc. (Feoktistova et al., 2013, 2016; Surov et al., 2016). In Simferopol (the capital of Republic of Crimea) the Common hamster was known since 1907 (Ognev, 1924) but an abundant urban population was firstly registered since the $70^{\text {th }}$ of XX century (Tovpinets et al., 2006).

Burrows are essential for the species as a daytime residence; they are used as forage storehouses, as refugees to avoid danger, as breeding places and hibernacula. Hamster burrows may be up to 2 meters deep and usually are strongly branched. Main factors for burrowing are a depth of soil layer and level of subterranean water. Usually, one animal occupies a burrow except for females with their litter (Górecki, 1977). The hamster has both winter burrows (more deep and branched) and simpler summer ones (Grulich, 1981; Nechay, 2000). Burrows have two types of entrances, through the inclined and vertical channels. As a rule, there is no excavated material around the entrance of a vertical channel because soil and debris are removed through the inclined channel.

Tunnels are directed to the nest chamber, locating at a depth of $50-70 \mathrm{~cm}$ (Karaseva et al., 1999). In late July - August, hamsters leave summer burrows to arrange the winter retreats. This transition period usually lasts from late July until October (Karaseva, 1962). K. L. Novikov (1932) also mentioned the annual seasonal migrations of hamsters for modest distances connected with the arrangement of winter burrows. These burrows are situated usually not far from the summer ones within a distance of 5 $10 \mathrm{~m}$. The structure of burrows may vary greatly depending on soil and type of surrounding vegetation. In addition, it also depends on sex, age and abundance and changed during the year (Nechay, 2000).

Therefore, changes in burrow abundance and their distribution over the area might be important indicators of the population condition for the Common hamster in an urban environment.

The present paper describes seasonal changes in burrowing activity of the Common hamster at the experimental plot in the Simferopol city park.

\section{MATERIAL AND METHODS}

Description of the experimental plot. The test plot was set up in 2015. It covered an area of 2.2 ha and was situated in Simferopol city in the park named after Yury Gagarin $(34.1 \mathrm{~N}, 44.9 \mathrm{E})$. The vegetation here includes grass, brushwood and trees. In $2016-$ 2017 a record of all trees and shrubs with their taxonomic identification was performed (Table 1). Location of each tree was mapped using laser range finder and GPS navigation with sitting over the spatial grid of $10 \times 10 \mathrm{~m}$. Special tags reflecting their location within particular grid cell were put on trees. From one side the plot is bordered by a large city road - Kievskaya street, from the other side - by an asphalted lane, illuminated during night hours, with fast-food stalls and refuse containers. Third and fourth sides border with variable park amusements with appropriate lights and music (Figure).

Regular tree plantings were realized $50-60$ years ago and are represented by alleys of Lombardy poplar, Honey locust and some other. The central part of the plot was occupied by dominant tree species: ash-tree, maple, European walnut. They are scattered irregularly, due to their natural colonization. Shrubs are represented by such species as hazel, cherry-plum, bramble and a dog-rose. Shrubs are regularly thinned out as a part of 


\section{SEASONAL CHANGES IN BURROWING OF THE COMMON HAMSTER}

fire-prevention measures and with the intention to reduce the number of ticks, supposed vectors of infectious diseases. The park staff regularly eliminates old dead trees, grasses are cut periodically. So the landscape of the plot constantly changes. In all, 635 trees and shrubs of 25 species are registered on the plot (Table 1). Besides that, there are several concrete sculptures like the horse, camel, the hen with chickens dispersed on the plot.

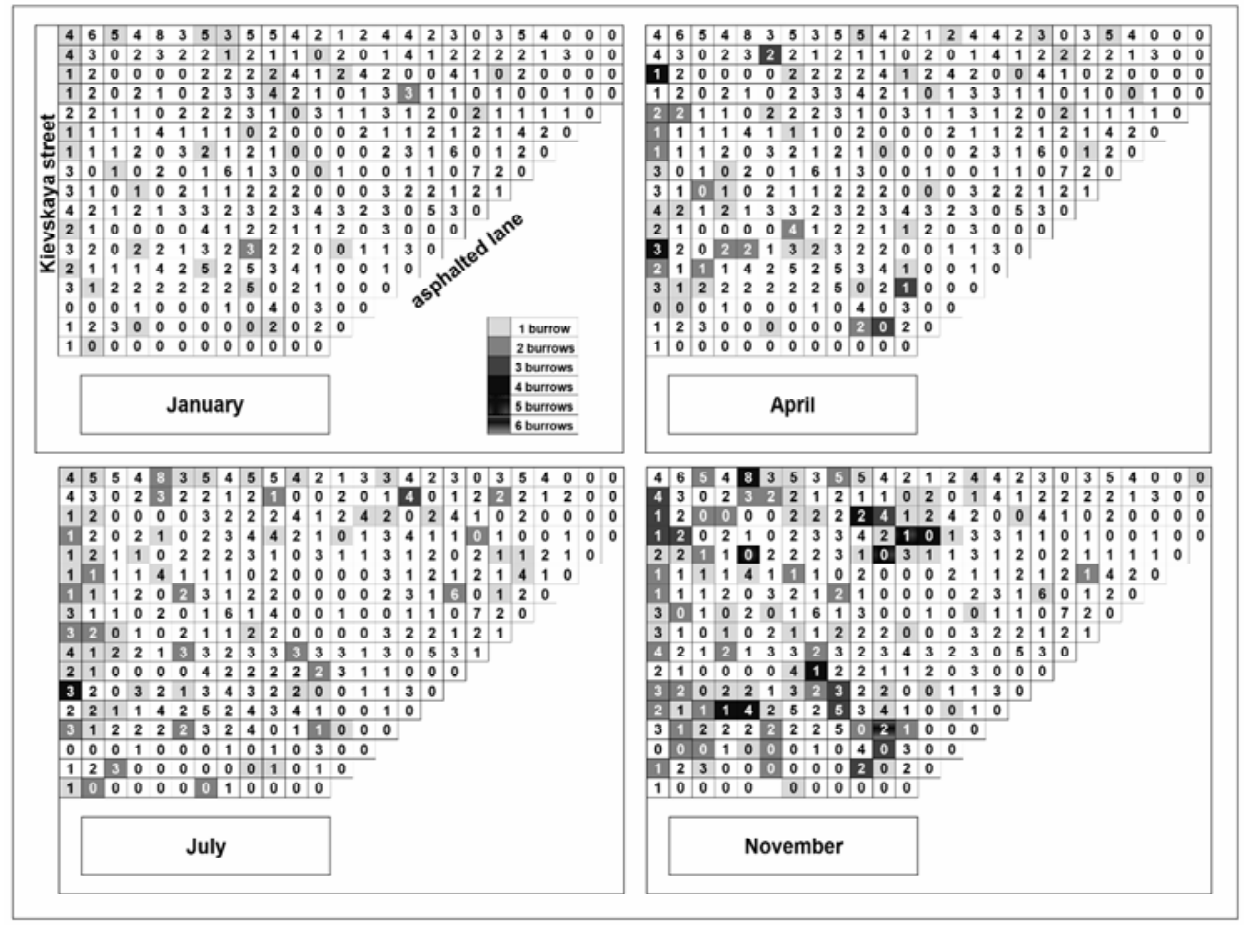

The density of the hamster burrows and the number of trees on the test plot.

Note: a character in the cell indicates a number of trees, fill rate - a number of burrows

Dominating species are European ash - Fraxinus excelsior L (115 sp.), Norway maple - Acer platanoides L. (108 sp), and European walnut - Juglans regia L. (68 sp). Such trees as white birch - Betula pendula L. and white mulberry Morus alba L. are represented by single specimens. The average density of trees is about 3 per $100 \mathrm{~m}^{2}$, but there are empty areas and areas with a higher coverage of trees.

The origin of all tree positions should be considered as complex one, because there are specially planted trees such as Lombardy poplar (Populus pyramidalis), Honey locust (Gleditsia triacanthos) and Eastern plane (Platanus orientalis), bordering alleys of the park, and at the same time the arrangement of dominating tree species - European ash (Fraxinus excelsior), Norway maple (Acer platanoides) and European walnut (Juglans regia) is coincidentally implying natural settlement. The presence of such trees as American arborvitae (Thuja occidentalis) and southern catalpa (Catalpa bignonioides) also may be explained by special planting by the park personnel. 
Elena A. Katzman, Elena A. Zaytseva, Natalia Yu. Feoktistova et al.

Table 1

List of trees and shrubs on the plot

\begin{tabular}{|c|c|c|c|}
\hline No. & Common name & Latin name & Number \\
\hline 1 & Cherry-plum & Prunus cerasifera & 12 \\
\hline 2 & White birch & Betula pendula & 1 \\
\hline 3 & Euonymus & Euonymus verrucosus & 2 \\
\hline 4 & Common willow & Salix alba & 8 \\
\hline 5 & Honey locust & Gleditsia triacanthos & 57 \\
\hline 6 & Common spruce & Picea abies & 4 \\
\hline 7 & White spruce & Picea glauca & 4 \\
\hline 8 & Southern catalpa & Catalpa bignonioides & 4 \\
\hline 9 & Norway maple & Acer platanoides & 108 \\
\hline 10 & Maple ash & Acer negundo & 8 \\
\hline 11 & Horse-chestnut & Aesculus hippocastanum & 12 \\
\hline 12 & European hazel & Corylus avellana & 18 \\
\hline 13 & Small-leaved lime & Tilia cordata & 11 \\
\hline 14 & European walnut & Juglans regia & 68 \\
\hline 15 & Eastern plane & Platanus orientalis & 51 \\
\hline 16 & Dogwood & Cornus alba & 7 \\
\hline 17 & Garden plum & Prunus domestica & 2 \\
\hline 18 & Scotch pine & Pinus sylvestris & 26 \\
\hline 19 & Swiss mountain pine & Pinus uncinata & 16 \\
\hline 20 & White poplar & Populus alba & 27 \\
\hline 21 & Lombardy poplar & Populus pyramidalis (Populus nigra) & 69 \\
\hline 22 & White mulberry & Morus alba & 1 \\
\hline 23 & American arborvitae & Thuja occidentalis & 3 \\
\hline 24 & Sweet moc-orange & Philadelphus coronarius & 1 \\
\hline 25 & European ash & Fraxinus excelsior & 115 \\
\hline
\end{tabular}

Mapping of burrows on the plot. Mapping of hamster burrows on the test plot was implemented four times - in winter (January), in spring (April), in summer (July) and in autumn (November). For complete registration of all burrows, three persons searched the entire plot, walking five meters apart from each other. During mapping the burrows were identified as: a new burrow (presently used) (inlet opening $7-10 \mathrm{~cm}$ in diameter is free or surrounded by amount of excavated material or soil) and old burrow (unused) - the entrance is closed entirely or partly by the soil (Table 2 ).

Table 2 During the whole

Seasonal change in burrowing activity and significance of association of presently used burrows with brushwood and tree vegetation

\begin{tabular}{l|c|c|c|c}
\hline \multicolumn{1}{c|}{ Month } & Unused burrows & Used burrows & $\chi^{2}$ & $P$ \\
\hline April & 40 & 70 & 2.3 & 0.127 \\
\hline July & 52 & 93 & 15.8 & 0.001 \\
\hline November & 84 & 174 & 7.7 & 0.006 \\
\hline January & 17 & 36 & 0.6 & 0.449 \\
\hline Mean $_{\text {seasons }}$ & 48.3 & 93.3 & 5.2 & 0.023
\end{tabular}

study period, samples of the material excavated by animals in the autumn and spring were collected. This material contains vegetable leftovers permitting indirectly to draw conclusions of the composition of 


\section{SEASONAL CHANGES IN BURROWING OF THE COMMON HAMSTER}

the diet. Five samples were studied, sorted out and vegetable remains found were listed in Table 3.

Table 3

Vegetable remains in material excavated from the common hamster burrows

\begin{tabular}{|c|c|c|c|}
\hline $\begin{array}{c}\text { Sample } \\
\text { no. }\end{array}$ & Species & Fragment's type & $\begin{array}{c}\text { Number } \\
\text { of fragments }\end{array}$ \\
\hline \multirow[t]{9}{*}{1} & Cherry-plum & Stone fragments & 12 \\
\hline & Cherry & Stone & 1 \\
\hline & Eastern plane & Intact nutlets & 1 \\
\hline & European ash & Intact seeds & 10 \\
\hline & European walnut & Shell fragments & 13 \\
\hline & Grasses (Bluegrass, Rye-grass etc.) & Small intact seeds & $>100$ \\
\hline & Honey locust & Parts of a pod, (small, $4-5 \mathrm{~mm}$ long) & 25 \\
\hline & Horse-chestnut & Whole fruit & 1 \\
\hline & Horse-chestnut & Shell fragments & 4 \\
\hline \multirow[t]{8}{*}{2} & Apricot & Half of the fruit with intact stone & 1 \\
\hline & Cherry-plum & Stone fragments & 5 \\
\hline & European ash & Intact seeds & 3 \\
\hline & European walnut & Shell fragments & 21 \\
\hline & Grasses (Bluegrass, Rye-grass etc.) & Small intact seeds & $>100$ \\
\hline & Honey locust & Parts of a pod, (small, 4-5 mm long) & 11 \\
\hline & Horse-chestnut & Whole fruits & 2 \\
\hline & Norway maple & Samaras & 2 \\
\hline \multirow[t]{6}{*}{3} & European ash & Intact seeds & 12 \\
\hline & European walnut & Shell fragments, half of a nut with kernel & 9,1 \\
\hline & Garlic mustard & Intact seeds & 31 \\
\hline & Grasses (Bluegrass, Rye-grass etc.) & Small intact seeds & $>100$ \\
\hline & Honey locust & Parts of a pod, (large, $10-12 \mathrm{~mm}$ long) & 18 \\
\hline & Norway maple & Samaras & 1 \\
\hline \multirow[t]{8}{*}{4} & Eastern plane & Intact nutlets & 1 \\
\hline & European ash & Intact seeds & 5 \\
\hline & European walnut & Shell fragments & 9 \\
\hline & Grasses (Bluegrass, Rye-grass etc.) & Small intact seeds & $>100$ \\
\hline & Honey locust & Parts of a pod, (small, 4-5 mm long) & 12 \\
\hline & Horse-chestnut & Intact chestnuts & 2 \\
\hline & Horse-chestnut & Shell fragments & 6 \\
\hline & Southern catalpa & Parts of a pod, $5-7 \mathrm{~mm}$ & 6 \\
\hline \multirow[t]{8}{*}{5} & Apple-tree & Fruitcase & 1 \\
\hline & Cherry-plum & Shell fragments & 3 \\
\hline & European ash & Intact seeds & 3 \\
\hline & European walnut & Shell fragments & 5 \\
\hline & Grasses (Bluegrass, Rye-grass etc.) & Small intact seeds & $>100$ \\
\hline & Horse-chestnut & Shell fragments & 4 \\
\hline & Honey locust & Parts of a pod, $5-7 \mathrm{~mm}$ & 7 \\
\hline & Maple ash & Samaras & 8 \\
\hline
\end{tabular}

Statistic methods. We ranged plot squares four category: with trees and burrows, with trees and without burrows, with burrows and without trees, without trees and burrows. These squares are calculated in accordance with the specified categories and statistically processed by the $\chi^{2}$-test. 


\section{RESULTS AND DISCUSSION}

Figure shows seasonal changes in the distribution of burrows in the test plot. Obviously, the largest number of burrows was registered in November (Table 2), when hamsters actively prepare new winter burrows and clear up the old ones. Note that in January, when the common hamster is usually hibernated, we also recorded the presently used burrows, but their number was five times less than in November.

Is the burrow distribution connected with the presence of trees in particular square? We tested this assumption using the annual and seasonal number of the burrows and presence of trees in particular grid cell. The number of hamster burrows associated with trees was significantly higher than the number of burrows not associated with trees if we took in account annual data (Table 2). However, seasonal distribution had some particular features. Therefore, in January and in April, these connections have not been statistically significant.

Another indirect factor to affect the position and distribution of burrows is managed cutting of trees and shrubs by the staff of the park, leading to notable changes of the landscape. In spring and summer, 2017, the central part of the plot was not densely populated because of cutting shrubs which led to a subsequent displacement of animals to the periphery with thick vegetation. Thus in different seasons hamsters are redistributed over the territory, occupying more convenient microhabitats. Certainly, the character of vegetation is directly associated with soil composition and in its turn defines digging capabilities for hamsters.

A deep trench and earth embankment go along the Kievskaya street (Figure) separating the park territory from the highway. A line of planted shrubs goes parallel to the trench in the park, and an alley of white poplars (Populus alba) was planted along the road. Dense vegetation represents good protection for numerous burrows registered in this place the whole year round. Earth embankment with soft soil is very convenient for digging being another factor favoring arrangement of burrows in this area. These factors may be regarded as crucial for the selection by hamsters a good place to dig a burrow.

Main forage plants of the Common hamsters inhabiting the plot were determined using the results presented in Table 3. These are a honey locust, European walnut, cherry-plum, and two species of chestnut. It should be noted that foraging animals might travel outside the plot area to adjacent zones with planted fruit trees. That is why samples contain fragments of plants which are absent on the plot, such as apricot and cherry. Numerous fragments of cherry-plum' stones were found in samples though only 12 specimens of this plant grow on the plot. Some remains such as nutlets of plane, maple's samaras and seeds of ash seemingly are of no feeding value, because all of them were found intact.

The arrangement of young trees of walnut which frequently grow from old burrows of the common hamster, gives evidence of zoochoric spreading of this plant with the hamster as an agent.

Therefore, the arrangement of burrows, their number, and pattern of their use as well as foraging resources and other characteristics are evidence of favorable conditions for supporting a high abundance of the common hamster in urban environment as compared with the wild habitats. 


\section{SEASONAL CHANGES IN BURROWING OF THE COMMON HAMSTER}

\section{Acknowledgments}

The authors are grateful to Ulrich Weinhold, initiator of the International Common Hamster Workgroup, director of the Institut für Faunistik, Heiligkreuzsteinach, Germany, for valuable suggestions on improving the manuscript.

This work was supported by the Russian Foundation for Basic Research (project no. 17-04-01061) and by the Presidium of the Russian Academy of Sciences (project no. 41 "Biodiversity of natural systems and biological resources of Russia").

\section{REFERENCES}

Feoktistova N. Yu., Surov A. V., Tovpinetz N. N., Kropotkina M. V., Bogomolov P. L., Siutz C., Haberl W., Hoffman I. The Common hamster as a synurbist: a history of settlement in European cities. Zoologica Poloniae, 2013, vol. 58, iss. 3-4, pp. 113-126.

Feoktistova N. Yu., Meschersky I. G., Surov A. V., Bogomolov P. L., Tovpinetz N. N., Poplavskaia N. S. Genetic Structure of Urban Population of the Common Hamster (Cricetus cricetus). Russian J. of Genetics, 2016, vol. 52, iss. 2, pp. 194-203.

Górecki A. Consumption by and agricultural impact of the Common hamster Cricetus cricetus (L.) on cultivated fields. Bull. OEPP, 1977, vol. 7, pp. 423-429.

Grulich I. Die baue des Hamsters (Cricetus cricetus, Rodentia, Mammalia). Folia Zoologica, 1981, vol. 30, iss. 2, pp. 99-116.

Karaseva E. V. Izuchenie s pomoshyu mecheniya osobennostey ispolzovaniya territorii obyknovennogo khomyaka $\mathrm{v}$ Altayskom kraye [The study of the peculiarities of territory use by the hamster in Altay province carried out by capture-recapture method]. Zoologicheskii zhurnal, 1962, vol. 41, pp. 275-285 (in Russian).

Karaseva E. V., Telitsina A. Y., Samoilov B. L. Mlekopitayushchie Moskvy v proshlom i nastoyaschem [Mammals of Moscow in the past and in the present]. Moscow, Nauka Publ., 1999. 244 p. (in Russian).

Lahr E. C., Dunn R. R., Frank S. D. Getting ahead of the curve: cities as surrogates for global change. Proceedings of the Royal Society B: Biological Sciences, 2018, vol. 285, iss. 1882, p. 20180643. DOI: https://doi.org/10.1098/rspb.2018.0643

Nechay G. Status of hamsters Cricetus cricetus, Cricetus migratorius, Mesocricetus newtoni and other hamster species in Europe. Nature and Environment series. Strasbourg, Council Europe Publ., 2000, no. 106. 78 p.

Novikov K. L. Khomyak obyknovenny [The common hamster]. Moscow, Vneshtorgizdat, 1932. 28 p. (in Russian).

Ognev S. I. Gryzuny Severnogo Kavkaza [The rodents of the North Caucasus]. Rostov-naDonu, Gosizdat Publ., 1924. 64 p. (in Russian).

Surov A. V., Poplavskaya N. S., Bogomolov P. L., Kropotkina M. V., Tovpinetz N. N., Katzman E. A., Feoktistova N. Yu. Synurbization of the Common Hamster (Cricetus cricetus L., 1758). Russian J. of Biological Invasions, 2016, vol. 7, no. 1, pp. 69-76.

Tovpinetz N. N., Evstafiev I. L., Karaseva E. V. Sklonnost k sinantropii u obyknovennogo khomyaka (Cricetus cricetus) na osnove issledovaniy v Krymu [Tendency to synanthropy in the Common hamster (Cricetus cricetus) based on investigations in the Crimea]. In: I. Zagorodnyuk, ed. Fauna in Anthropogenic Environments. Uzhhorod, Pryvatna drukarnya Romana Povcha, 2006, pp. 136-145.

World urbanization prospects: the 2014 revision, Highlights. ST/ESA/ SER.A/352. New York, UN DESA, 2014. 
Elena A. Katzman, Elena A. Zaytseva, Natalia Yu. Feoktistova et al.

УДК 599.323.42:574

\title{
СЕЗОННАЯ ДИНАМИКА В ИСПОЛЬЗОВАНИИ НОР У ОБЫКНОВЕННОГО ХОМЯКА (CRICETUS CRICETUS L., 1758) (RODENTIA: CRICETIDAE) В ГОРОДЕ
}

\author{
Е. А. Кацман, Е. А. Зайцева, Н. Ю. Феоктистова, Н. Н. Товпинец, \\ П. Л. Богомолов, Е. В. Поташникова, А. В. Суров \\ Институт проблем экологии и эволючии им. А. Н. Северцова РАН \\ Россия, 117071, Москва, Ленинский просп., 33 \\ E-mail:feoktistovanyu@gmail.com
}

Поступила в редакцию 14.04.2018 г., после доработки 17.05.2018 г., принята 23.08.2018 г.

\begin{abstract}
Katzman E. A., Zaytseva E. A., Feoktistova N. Yu., Tovpinetz N. N., Bogomolov P. L., Potashnikova E. V., Surov A. V. Seasonal Changes in Burrowing of the Common Hamster (Cricetus cricetus L., 1758) (Rodentia: Cricetidae) in the City [Каџман E. А., Зайцева Е. А., Феоктистова Н. Ю., Товпинеи Н. Н., Богомолов П. Л., Поташникова Е. В., Суров А. В. Сезонная динамика в использовании нор у обыкновенного хомяка (Cricetus cricetus L., 1758) (Rodentia: Cricetidae) в городе] // Поволжский экологический журнал. 2018. № 3. C. 251 - 258. DOI: https://doi.org/10.18500/1684-7318-2018-3-251-258
\end{abstract}

Обыкновенный хомяк (Cricetus cricetus) в последние десятилетия интенсивно заселяет города. Изменения в количестве нор и их распределении по территории могут быть важными индикаторами популяционного статуса этого вида в городской среде. В данном исследовании рассматривается характер распределения нор на экспериментальной площадке (2.2 га), расположенной в городском парке г. Симферополь. Предварительно на площадке была детально закартирована древесно-кустарниковая растительность. Жилые норы хомяков наносились на эту карту один раз в квартал в течение года. Показано, что наибольшее количество активно используемых нор приходилось на ноябрь. Интересно, что наземная активность хомяков сохранялась даже в самый холодный месяц года (январь), но число используемых нор в это время было минимальным. Квадраты, в которых присутствовали и деревья и норы (по среднегодовым показателям), встречались достоверно чаще, чем норы в квадратах, лишенных деревьев $\left(P=0.02, \chi^{2}=5.4\right)$, но это не относится к зимнему и весеннему сезонам. Мы предполагаем, что связь нор с кустарниковой и древесной растительностью облегчает норостроение, обеспечивает лучшую защиту от хищников и является источником корма. Все эти факторы обеспечивают условия для поддержания высокой численности обыкновенного хомяка в городской среде.

Ключевые слова: обыкновенный хомяк, норы, городская популяция, растительность.

DOI: https://doi.org/10.18500/1684-7318-2018-3-251-258

Благодарности. Работа выполнена при финансовой поддержке Российского фонда фундаментальных исследований (проект № 17-04-01061) и Программы Президиума РАН (проект № 41 «Биоразнообразие природных систем и биологических ресурсов России»). 